\title{
PRAKTIK OPEN GOVERNMENT MELALUI PARTISIPASI PUBLIK DI KABUPATEN BOJONEGORO DALAM MEWUJUDKAN TRANSPARANSI DAN AKUNTABILITAS
}

\author{
*Berlian Tyasotyaningrum \\ Fakultas Ilmu Sosial dan Politik, Universitas Kadiri, Indonesia \\ *Email Korespondensi : berlian.tyasotyaningrum@gmail.com
}

\begin{abstract}
Abstrak
Partisipasi publik melalui Dialog Publik Jumat di kabupaten Bojonegoro merupakan salah satu wujud praktik open government dalam mewujudkan transparansi dan akuntabilitas. Melalui inovasi pembangunan partisipasi publik tersebut, kabupaten Bojonegoro telah mendapatkan prestasi sebagai proyek percontohan open government di dunia. Penelitian ini menggunakan teknik penelitian kualitatif dengan metode deskriptif. Studi ini bertujuan untuk mengidentifikasi bagaimana praktik open government melalui partisipasi publik dapat mewujudkan transparansi dan akuntabilitas di kabupaten Bojonegoro. Hasil studi menunjukkan bahwa open government melalui dialog publik dapat mewujudkan transparansi berupa: penyampaian informasi terkait sosialisasi program-program pemerintah, finansial dan penyelenggaraan pelayanan publik. Sedangkan akuntabilitas yang terwujud melalui dialog publik terkait kinerja pemerintah dan pelayanan publik. Dialog publik memiliki peran dalam mewujudkan praktik transparansi dan akuntabilitas di kabupaten Bojonegoro, yaitu : meningkatkan kepercayaan publik, membentuk legitimasi masyarakat serta memperbaiki pengambilan keputusan. Pembelajaran dari inovasi partisipasi publik melalui dialog publik di kabupaten Bojonegoro adalah: pentingnya komunikasi langsung antara pejabat publik dan masyarakat, pentingnya peran pemimpin sebagai pelatih, dan partisipasi publik memastikan bahwa pemerintah selalu terhubung dengan masyarakatnya.
\end{abstract}

Kata Kunci: open government; partisispasi publik; transparansi.

\begin{abstract}
Public participation through the Friday Public Dialogue in Bojonegoro district is a form of open government practice in realizing transparency and accountability. Through these public participation development innovations, Bojonegoro district has gained achievements as a pilot project for open government in the world. This research uses qualitative research techniques with descriptive methods. This study aims to identify how open government practices through public participation can achieve transparency and accountability in the Bojonegoro district. The results of the study show that open government through public dialogue can achieve transparency in the form of delivery of information related to the socialization of government programs, finance, and public service delivery. Meanwhile, accountability is realized through public dialogue related to government performance and public services. Public dialogue has a role in realizing transparency and accountability practices in the Bojonegoro district, namely: increasing public trust, establishing community legitimacy, and improving decision-making. Lessons learned from public participation innovation through public dialogue in Bojonegoro district are the importance of direct communication between public officials and the community,
\end{abstract}


the importance of the role of leaders as trainers, and public participation to ensure that the government is always connected to its people.

Keywords: open government; public participation; transparency.

\section{PENDAHULUAN}

Dialog publik jumat merupakan salah satu inovasi pembangunan partisipasi publik dan salah satu bentuk inovasi yang menjadi unggulan di Kabupaten Bojonegoro (Habibah, 2017). Partisipasi publik melalui Dialog Publik Jumat di Kabupaten Bojonegoro merupakan salah satu wujud praktik open government dalam mewujudkan transparansi dan akuntabilitas di Kabupaten Bojonegoro. Melalui inovasi pembangunan partisipasi publik tersebut, Kabupaten Bojonegoro telah mendapatkan prestasi sebagai proyek percontohan open government di dunia (Safarov et al., 2017).

Open government menurut Global Integrity (Lauranti et al., 2017) mencakup tiga hal yakni transparansi informasi, keterlibatan publik dan akuntabilitas. Melalui transparansi, masyarakat memahami cara kerja pemerintah. Dengan keterlibatan publik, maka publik dapat mempengaruhi cara kerja pemerintah dalam proses kebijakan pemerintah dan pelayanan publik. Akuntabilitas bermakna bahwa masyarakat dapat meminta pemerintah mempertanggungjawabkan kinerja kebijakan dan pelayanannya. Open government dilakukan sebagai upaya untuk meningkatkan transparansi, partisipasi, dan akuntabilitas pemerintah untuk memulihkan kepercayaan masyarakat (Nawawi, 2012). Dengan demikian, open government merupakan sebuah konsep bagus untuk menjembatani interaksi antara birokrat dan masyarakat.

Inovasi pembangunan partisipasi publik melalui Dialog Publik Jumat muncul pada tahun 2008 saat Suyoto (Bupati Bojonegoro periode 2008-2018) melaksanakan kampanye pencalonan Bupati. Inovasi ini dilatarbelakangi atas berbagai kekhawatiran masyarakat terhadap janji politik yang diberikan Suyoto (2018). Kemudian Suyoto memperoleh masukan dari salah satu tokoh masyarakat yang terispirasi dari kegiatan di Timor-Timor untuk melakukan kegiatan dialog di pendopo setiap jumat agar masyarakat bisa menagih janji Suyoto. Kegiatan Dialog Publik Jumat tersebut membantu memfasilitasi dan menjembatani diskusi interaktif antara pejabat publik dan masyarakat. 
Dengan demikian adanya partisipasi publik melalui dialog publik tersebut selain bermanfaat bagi masyarakat juga bermanfaat bagi pejabat publik.

Partisipasi publik dalam administrasi publik sebagai sarana untuk kerjasama dengan masyarakat dalam meningkatkan nilai demokrasi seperti transparansi dan akuntabilitas (Kim \& Lee, 2017). Pengalaman masyarakat pada kegiatan partisipasi aktif dapat menjadi hubungan positif dengan penilaian transparansi di pemerintah daerah (Kim \& Lee, 2017). Secara konseptual, partisipasi publik merupakan strategi yang penting untuk menyalurkan aspirasi masyarakat dalam proses pemerintahan daerah (Duadji, 2013). Peningkatan keterlibatan masyarakat mengarah pada aspirasi masyarakat yang lebih besar dalam pengambilan keputusan serta peningkatan akuntabilitas (Sharma, 2008). Dengan demikian, partisipasi publik sangat berkaitan dengan transparansi dan akuntabilitas.

Berdasarkan pernyataan di atas, menunjukkan bahwa partisipasi publik sangat berkaitan dengan transparansi dan akuntabilitas. Oleh sebab itu, partisipasi publik melalui dialog publik jumat memiliki peran dalam pelaksanaan praktik transparansi dan akuntabilitas di kabupaten Bojonegoro. Dengan demikian, penelitian ini dilakukan untuk mengidentifikasi bagaimana praktik open government melalui partisipasi publik, khusunya Dialog Publik Jumat dapat mewujudkan transparansi dan akuntabilitas di kabupaten Bojonegoro.

\section{TINJAUAN PUSTAKA}

Selaras dengan penelitian yang dilakukan oleh (Habibah, 2017) dengan judul penelitian Efektifitas Dialog Jumat Sebagai Model Pembuatan Kebijakan Publik Deliberatif di Kabupaten Bojonegoro. Adapun penelitian yang menggunakan tipe analisis kualitatif dengan analisis kualitatif. Teknik yang digunakan untuk mengumpulkan data dengan Teknik wawancara, observasi serta dokumentasi yang ditentukan dengan teknik purposive dan snowball dimana data disajikan dengan absah. Hasil pada penelitian ini menunjukkan bahwa masyarakat menunjukkan partisipasi yang tinggi dengan adanya pelaksanaan Dialog Jumat dalam menerima program ini dengan baik. Karena dengan adanya Dialog Jumat ini memberikan ruang untuk masyarakat 
untuk berkomunikasi secara luas karena hasil dari Dialog Jumat menjadi pengaruh terhadap kebijakan yang sudah atau yang akan dilaksanakan dalam waktu mendatang.

\section{METODE PENELITIAN}

Pada penelitian ini menggunakan penelitian kualitatif dengan metode deskriptif. Teknik yang digunakan pada penelitian ini adalah Purposive Random Sampling. Dimana data didapatkan dari observasi, wawancara serta dokumentasi yang dilakukan di Kabupaten Bojonegoro melalui media Dialog Publik Jumat merupakan salah satu wujud praktik open government dalam mewujudkan transparansi dan akuntabilitas.

\section{HASIL DAN PEMBAHASAN}

\section{Inisiasi Program Dialog Publik Jumat di Kabupaten Bojonegoro}

Pada dasarnya Pemerintah Kabupaten Bojonegoro sejak tanggal 15 Maret 2008 telah menfasilitasi hak masyarakat untuk memperoleh informasi publik melalui media dialog publik yang memberikan akses seluas-luasnya kepada seluruh lapisan masyarakat untuk menyampaikan aspirasinya. Dialog Publik menjadi sarana warga untuk melakukan verifikasi terhadap semua media keluhan masyarakat lainnya. Dialog publik, dilaksanakan secara rutin setiap Hari Jum'at Pukul 13.00 sampai 15.00 WIB. Masyarakat bebas hadir, menyuarakan aspirasinya, mengadukan permasalahan apapun, saran, kritik, memohon informasi, bahkan hingga masalah pribadi. Semua didengar ditampung, dijawab, dipenuhi secara terbuka oleh Bupati, Wakil Bupati, Sekretaris Daerah dan seluruh Kepala SKPD (PPID Kabupaten Bojonegoro, 2015).

Inisiatif dialog publik jumat muncul pada saat Suyoto akan melaksanakan kampanye pemilu Bupati Bojonegoro tahun 2008. Suyoto (2018) menerangkan bahwa saat melakukan kampanye, bermunculan berbagai kekhawatiran masyarakat terhadap janji yang diberikannya. Dialog publik jumat yang digagas Suyoto di kabupaten Bojonegoro berawal dari usulan mbah Har yang terinspirasi dari kegiatan di TimorTimor yang membuka diskusi di pendopo setiap habis sholat jumat. Kemudian inspirasi tersebut ditidaklanjuti oleh Suyoto setelah dilantik menjadi Bupati Bojonegoro pada tanggal 12 Maret 2008. Pada tanggal 14 Maret 2008 atau dua hari setelah pelantikan 
bupati dan wakil bupati kabupaten Bojonegoro, dialog publik tersebut pertama kali dilaksanakan.

Menurut penuturan Suyoto (2018), pada awalnya tujuan dialog publik adalah untuk menagih janji politik Kang Yoto kepada rakyat pada saat kampanye pemilu 2008. Dialog publik tersebut digunakan sebagai sarana untuk melakukan sosialisasi dan menjadi sebuah asuransi demokrasi sosial. Dengan demikian, secara langsung maupun tidak langsung dialog publik tersebut memberikan manfaat yang signifikan baik kepada masyarakat maupun pejabat publik yaitu meningkatkan kepercayaan publik, menjadi saluran untuk mengundang partisipasi publik dan menjadi cara belajar bersama sehingga bisa dilakukan inovasi (Musthofa, 2016).

\section{Implementasi Dialog Publik Jumat di Kabupaten Bojonegoro}

Berbeda dengan dialog-dialog yang biasa digelar oleh instansi pemerintah di daerah lain, Dialog Publik di Kabupaten Bojonegoro bersifat terbuka. Semua masyarakat bisa datang tanpa prosedur protokoler yang biasa diberlakukan. Berdasarkan informasi dari Dinas Kominfo, peserta dan aktor yang terlibat dalam dialog publik jumat yaitu seluruh perwakilan dari OPD Kabupaten Bojonegoro, masyarakat Bojonegoro, masyarakat luar Bojonegoro, pelaku UKM, kelompok-kelompok masyarakat (kelompok tani, kelompok PKL, dan lain-lain). Aktor pada dialog publik jumat meliputi Bupati, Wakil Bupati, OPD. Dalam rangka memperluas informasi kepada masyarakat, dialog publik juga disiarkan langsung melalui radio pemerintah dan swasta yaitu radio Malowopati FM dan radio Madani FM.

Berdasarkan observasi langsung yang dilakukan oleh peneliti, teknisnya dalam dialog publik jumat adalah sebagai berikut:

1. Peserta dialog publik jumat mengisi daftar hadir

2. Pembukaan dialog publik jumat oleh moderator yang telah ditunjuk oleh Dinas Kominfo.

3. Pemaparan seputar isu terkini dan/atau laporan dari OPD maupun organisasi publik lainnya. Biasanya pemaparan berupa sosialisasi program, laporan keuangan, pemaparan seputar isu terkini maupun laporan kinerja dari oleh salah satu atau beberapa OPD setiap minggunya. 
Salah satu contoh sosialisasi program OPD terjadi pada tanggal 6 Januari 2017 dengan narasumber Dinas Pertanian Kabupaten Bojonegoro yang menyampaikan topik tentang "Pengendalian hama penyakit serta rencana distribusi pupuk Tahun 2017.” (Dinas Kominfo Kabupaten Bojonegoro, 2018)

4. Penyampaian aspirasi masyarakat dilakukan secara bergantian baik perorangan maupun kelompok. Masyarakat diberikan kesempatan berinteraksi langsung dengan pejabat publik yang bersangkutan. Masyarakat tidak diberikan batasan dalam menyampaikan aspirasinya.

5. Tanggapan langsung dari OPD terkait sesuai dengan pertanyaan maupun kritik masyarakat.

6. Penutupan dialog publik jumat oleh moderator. Sebelum acara ditutup, terlebih dahulu Bupati Bojonegoro memberikan pengarahan yang berkaitan dengan keluhan atau pengaduan masyarakat saat itu. Setelah pengarahan dari bupati selesai, selanjutnya acara ditutup oleh moderator.

Berdasarkan proses pelaksanaan dialog publik tersebut, terlihat bahwa pada dialog publik Jumat komunikasi antara pejabat publik dan masyarakat tersebut bersifat dialogis. Dimana komunikasinya dua arah antara pejabat publik dan masyarakat secara terbuka dan komunikatif. Masyarakat secara bergantian diberikan ruang untuk berkomunikasi langsung dengan pejabat publik di Kabupaten Bojonegoro. Setelah masyarakat menyampaikan aspirasinya kepada pemerintah, pemerintah langsung memberikan timbal balik terhadap aspirasi masyarakat tersebut.

Dalam rangka menjamin keberlanjutan dialog publik, Pemerintah Kabupaten Bojonegoro sudah membuat dasar hukum melalui Surat Keputusan (SK) Bupati Bojonegoro Nomor 188/305/KEP/412.12/2008 Tentang Dialog Publik antara Pemkab Bojonegoro dan Masyarakat Kebupaten Bojonegoro. Kemudian dari Surat Keputusan (SK) tersebut diterjemahkan dengan Surat Keputusan (SK) Kepala Dinas Infokom Kabupaten Bojonegoro Nomor 3 Tahun 2008 Tentang Penyelenggaraan Penyampaian Informasi dan Sosialisasi Dinas Infokom Kabupaten Bojonegoro . 
Peran Dialog Publik Jumat Dalam Melaksanakan Praktik Transparansi Dan Akuntabilitas Di Kabupaten Bojonegoro

Partisipasi publik melalui Dialog Publik Jumat di kabupaten Bojonegoro merupakan salah satu wujud implementasi open government di kabupaten Bojonegoro. Menurut Global Integrity (Lauranti et al., 2017) open government mencakup tiga hal yakni transparansi informasi, keterlibatan publik dan akuntabilitas. Berikut ini prinsip open government yang ada pada Dialog Publik Jumat:

\section{Transparansi}

Dialog Publik Jumat sebagai sarana Pemerintah dalam melaksanakan keterbukaan informasi kepada masyarakat. Keterbukaan informasi pada Dialog Publik Jumat di kabupaten Bojonegoro berupa:

1. Penyampaian informasi terkait sosialisasi program-program pemerintah Program kerja pemerintah tersebut tentunya tidak dapat terealisasikan

Tanpa adanya sosialisasi kepada masyarakat. Oleh karena itu perlu dilakukan sosialisasi untuk menyebarkan informasi program pemerintah tersebut kepada masyarakat. Salah satu contoh program pembangunan pemerintah kabupaten Bojonegoro yang disosialisasikan dalam dialog publik jumat yaitu program dari DP3AKB Kabupaten Bojonegoro. Program dari DP3AKB Kabupaten Bojonegoro yaitu Upaya peningkatan pemberdayaan perempuan dalam mendukung program Kampung $\mathrm{KB}$, Program tersebut disosialisasikan pada dialog publik jumat edisi 182 tanggal 28 April 2017 (Dinas Kominfo Kabupaten Bojonegoro, 2018). Dengan demikian tercipta transparansi dalam penyampaian informasi terkait sosialisasi program-program pemerintah.

2. Penyampaian informasi terkait finansial

Pada Dialog Publik Jumat, masyarakat diberi kesempatan untuk ikut serta berpartisipasi dalam proses anggaran. Salah satu bentuk transparansi pada Dialog Publik Jumat secara finansial adalah sosialisasi dan laporan terkait keuangan. Sosialisasi dan laporan terkait finansial tersebut penting dilakukan agar masyarakat mengetahui tentang aturan, prosedur dan bahkan laporan terkait keuangan pemerintahan. Dengan adanya sosialisasi tersebut membuat masyarakat mengerti terkait aturan dan prosedur terkait 
keuangan pemerintah, sehingga memudahkan masyarakat melakukan aktivitas yang berhubungan dengan urusan finansial dalam pemerintahan. Berikut ini beberapa contoh sosialisasi terkait finansial pada dialog publik jumat.

Tabel 1 Sosialisasi Terkait Finansial dalam Dialog Publik Jumat

\begin{tabular}{|c|c|l|l|l|}
\hline No & Edisi & \multicolumn{1}{|c|}{ Tanggal } & \multicolumn{1}{|c|}{ Topik } & \multicolumn{1}{|c|}{ Narasumber } \\
\hline 1 & 168 & $\begin{array}{l}\text { 11 Januari } \\
2017\end{array}$ & $\begin{array}{l}\text { Penyerahan klaim asuransi } \\
\text { pertanian dari PT. Jasindo } \\
\text { oleh Bapak Bupati ke Petani }\end{array}$ & Bupati \\
\hline 2 & 171 & $\begin{array}{l}3 \text { Februari } \\
2017\end{array}$ & $\begin{array}{l}\text { Biaya pembuatan STNK dan } \\
\text { BPKB }\end{array}$ & $\begin{array}{l}\text { UPT Badan Pendapatan Daerah } \\
\text { Provinsi Jawa Timur di } \\
\text { Bojonegoro }\end{array}$ \\
\hline 3 & 172 & $\begin{array}{l}10 \text { Februari } \\
2017\end{array}$ & $\begin{array}{l}\text { Besaran tarif dasar listrik } \\
\text { dan } \\
\text { sasaran subsidinya }\end{array}$ & $\begin{array}{l}\text { PT. PLN APJ Kabupaten } \\
\text { Bojonegoro }\end{array}$ \\
\hline
\end{tabular}

Sumber: Dinas Kominfo Kabupaten Bojonegoro diolah penulis, 2018

Berdasarkan data di atas menunjukkan bahwa transparansi secara finansial dapat dilakukan dengan cara yang sederhana. Dengan sosialisasi seperti ini dapat menciptakan interaksi langsung masyarakat dengan pemerintah, sehingga masyarakat dapat dengan mudah memahani tata keuangan pemerintahan. Interaksi secara langsung tersebut meminimalkan terjadinya kesalahan persepsi antara pemerintah dan masyarakat. Dengan demikian masyarakat dapat mengerti dan mengerti terhadap sosialisasi yang dipikirkan dan dilakukan pemerintah. Hal tersebut dapat menciptakan transparansi secara finansial, juga dapat meningkatkan kepercayaan masyarakat terhadap pemerintah khususnya terkait urusan finansial.

3. Penyampaian informasi terkait penyelenggaraan pelayanan publik baik dari proses kebijakan, perencanaan, pelaksanaan serta monitoring dan evaluasi pelayanan publik.

Pada dialog publik jumat di Kabupaten Bojonegoro, salah satu bentuk informasi pemberian pelayanan publik yaitu sosialisasi program pelayanan publik kepada masyarakat dan aduan masyarakat terkait kualitas pelayanan publik. Dalam penyampaian layanan tersebut, masyarakat dan pelaku usaha dilibatkan agar mewujudkan suatu pelayanan publik yang baik dan berkualitas, serta sejalan dengan kebutuhan masyarakat. Oleh karena itu diperlukan perhatian semua pihak mulai dari pemerintah sebagai pembuat regulasi, aparatur negara sebagai pelaksana, serta 
masyarakat dan pihak swasta sebagai pengawas jalannya pelayanan publik. Berikut ini adalah beberapa contoh sosialisasi pemberian layanan pada dialog publik jumat.

Tabel 2 Informasi Pemberian Layanan pada Dialog Publik Jumat

\begin{tabular}{|c|c|c|l|l|}
\hline No & Edisi & Tanggal & \multicolumn{1}{c|}{ Topik } & \multicolumn{1}{c|}{ Narasumber } \\
\hline 1 & 177 & 17 Maret 2017 & $\begin{array}{l}\text { Prosedur pemberian bantuan } \\
\text { pendidikan bagi mahasiswa }\end{array}$ & $\begin{array}{l}\text { Bagian Kesejahteraan Rakyat } \\
\text { Setda } \\
\text { Kabupaten Bojonegoro }\end{array}$ \\
\hline 2 & 180 & 7 April 2017 & $\begin{array}{l}\text { Langkah-langkah dalam } \\
\text { menarik investasi/ modal }\end{array}$ & $\begin{array}{l}\text { Dinas Penanaman Modal dan } \\
\text { Pelayanan Terpadu Satu Pintu } \\
\text { Kabupaten Bojonegoro }\end{array}$ \\
\cline { 4 - 5 } & & & $\begin{array}{l}\text { Mekanisme pemberian klaim } \\
\text { santunan korban kecelakaan }\end{array}$ & $\begin{array}{l}\text { PT. Jasa Raharja cabang } \\
\text { Bojonegoro }\end{array}$ \\
\hline 3 & 181 & 21 April 2017 & $\begin{array}{l}\text { Penjelasan terkait ijin } \\
\text { pertambangan }\end{array}$ & $\begin{array}{l}\text { Bagian Sumber Daya Alam Setda } \\
\text { Kabupaten Bojonegoro }\end{array}$ \\
\hline
\end{tabular}

Sumber: Dinas Kominfo Kabupaten Bojonegoro diolah penulis, 2018

Berdasarkan data di atas, menunjukkan bahwa dialog publik jumat dapat dijadikan sebagai media untuk pemberian informasi dan sosialisasi program pelayanan publik. Setelah masyarakat ataupun pihak swasta mengetahui prosedur pelayanan tersebut, maka akan dengan mudah pelayanan publik tersebut dilaksanakan. Melalui dialog publik jumat, pemerintah dapat melakukan transparansi informasi agar masyarakat memahami cara kerja pemerintah.

\section{Keterlibatan Publik}

Pada Dialog Publik Jumat, keterlibatan publik menjadi masukan kepada Pemerintah Kabupaten berupa aspirasi, saran, keluhan, koreksi dan permasalahan. Keterlibatan publik sehubungan dengan proses kebijakan pemerintah dan program pemberian layanan, dengan demikian keterlibatan publik dapat mempengaruhi cara kerja pemerintah. Berdasarkan hasil observasi, bentuk-bentuk aspirasi dari masyarakat dapat berupa:

a. Kritik dan usulan: berupa kritik dan usulan terhadap masalah yang terjadi baik di tingkat desa sampai fenomena yang masif terjadi di Kabupaten Bojonegoro. Selain itu kritik dan usulan bisa juga terhadap program pemerintah serta pembangunan yang terjadi di Kabupaten Bojonegoro, baik pembangunan yang sifatnya fisik maupun pembangunan Sumber Daya Manusia (SDM). 
b. Evaluasi dan monitoring: Dialog publik jumat, dapat dijadikan sebagai media untuk evaluasi serta monitoring program pemerintah mulai dari urusan pemerintah desa sampai kabupaten. Pada Dialog Publik Jumat, masyarakat dapat terlibat langsung dalam evaluasi dan mobitoring terkait kebijakan pemerintah dan program pelayanan publik yang diberikaan pemerintah.

c. Promosi masyarakat: Promosi pada dialog publik berupa promosi produk lokal yang dibuat oleh masyarakat ataupun kelompok masyarakat, misalnya : produk jamu, makanan ringan, produk UKM. Selain itu ada juga promosi pemberian jasa, seperti pijat. Bahkan ada juga yang promosi lagu dan puisi yang diciptakan. Salah satu contoh promosi adalah pada dialog publik edisi 85 periode II/2015, ada warga desa pumpungan bernama Fauzi seorang pengrajin souvenir bambu mempromosikan produknya secara langsung di dialog publik jumat.

Bentuk-bentuk aspirasi dari masyarakat tersebut dijadikan sebagai masukan untuk keberlangsungan Pemerintah Kabupaten Bojonegoro. Selain itu aspirasi masyarakat juga dijadikan pertimbangan pemerintah Kabupaten Bojonegoro dalam pembuatan kebijakan publik. Dengan demikian dialog publik dapat menciptakan proses interaksi secara seimbang antara pejabat publik dan masyarakat yang dapat dapat membangun paradigma kebijakan publik yang berorientasi pada aspirasi dan kebutuhan masyarakat.

\begin{abstract}
Akuntabilitas
Dialog Publik Jumat sebagai sarana Pemerintah dalam melaksanakan akuntabilitas. Akuntabilitas terjadi seiring dengan transparansi yang dilakukan pada Dialog Publik Jumat di kabupaten Bojonegoro. Pada Dialog Publik Jumat, masyarakat dapat meminta pemerintah mempertanggungjawabkan terkait:
\end{abstract}




\section{Akuntabilitas terkait kinerja pemerintah}

Dialog Publik Jumat menjadi sarana bagi pejabat publik untuk melakukan akuntabilitas terkait kinerja kebijakan. Pada dialog tersebut, pejabat publik melakukan akuntabilitas dengan cara menyampaikan rencana kinerja kebijakan, proses kinerja kebijakan, tujuan kebijakan tersebut dilakukan serta pertanggungjawaban atas kinerja kebijakan tersebut. Selain mempertanggungjawabkan kinerjanya terhadap masyarakat, pemerintah juga melibatkan masyarakat dalam membuat kinerja kebijakan menjadi sukses. Dengan demikian dialog publik dapat menciptakan proses interaksi secara seimbang antara pejabat publik dan masyarakat yang dapat dapat membangun paradigma kebijakan publik yang berorientasi pada aspirasi dan kebutuhan masyarakat.

Berikut ini adalah beberapa contoh bentuk konsultasi antara pejabat publik dengan masyarakat terkait program kerja maupun pembuatan peraturan daerah.

Tabel 3 Konsultasi terkait Program Kerja Pemerintah Daerah

\begin{tabular}{|c|c|l|l|l|}
\hline No & Edisi & \multicolumn{1}{|c|}{ Tanggal } & \multicolumn{1}{|c|}{ Topik } & \multicolumn{1}{c|}{ Narasumber } \\
\hline 1 & 171 & 3 Februari & $\begin{array}{l}\text { Rencana pembangunan } \\
\text { jalan } \\
2017\end{array}$ & $\begin{array}{l}\text { Dinas Pekerjaan Umum Bina } \\
\text { Mahun 2017 serta penataan } \\
\text { dan Penataan Ruang } \\
\text { Kabupaten di Bojonegoro } \\
\text { Bojonegoro }\end{array}$ \\
\hline 2 & 172 & $\begin{array}{l}\text { 10 Februari } \\
2017\end{array}$ & $\begin{array}{l}\text { Rencana program kerja } \\
\text { Dinas } \\
\text { Perumahan Pemukiman dan } \\
\text { Cipta Karya Tahun 2017 }\end{array}$ & $\begin{array}{l}\text { Dinas Perumahan Pemukiman } \\
\text { dan } \\
\text { Cipta Karya }\end{array}$ \\
\hline 3 & 178 & $\begin{array}{l}24 \text { Maret } \\
2017\end{array}$ & $\begin{array}{l}\text { Rencana kerja serta target } \\
\text { tahun 2017 }\end{array}$ & $\begin{array}{l}\text { Dinas Pemuda dan Olahraga } \\
\text { Kabupaten Bojonegoro }\end{array}$ \\
\hline
\end{tabular}

Sumber : Dinas Kominfo Kabupaten Bojonegoro diolah penulis, 2018

Berdasarkan tabel di atas, dialog publik dijadikan media untuk mendiskusikan beberapa program kerja pemerintah. Hal tersebut menunjukkan bahwa masyarakat dilibatkan dalam kegiatan tata kelola pemerintah. Berdasarkan observasi, masyarakat diberikan ruang untuk menyampaikan saran maupun keluhan terhadap program kerja yang dipaparkan oleh salah satu perwakilan OPD tersebut. Dengan adanya keterlibatan masyarakat tersebut, sehingga kandungan keputusan tersebut mencerminkan pandangan dan tuntutan masyarakat. 


\section{Akuntabilitas terkait pelayanan}

Melalui dialog publik jumat, pejabat publik dapat mempertanggungjawabkan pelayanan publik yang diberikan kepada masyarakat. Dengan adanya transparansi terkait penyelenggaraan pelayanan publik baik dari proses kebijakan, perencanaan, pelaksanaan serta monitoring dan evaluasi pelayanan publik menunjukkan bahwa adanya praktik akuntabilitas pada Dialog Publik Jumat. Dimana pemerintah mempertanggungjawabkan dengan menyampaikan perencanaan, proses dan hasilnya pelayanan publik kepada masyarakat. Akuntabilitas terkait pelayanan pada dialog publik tersebut menciptakan komunikasi dialogis antara pejabat pembuat pelayanan publik dan masyarakat, selain itu saran maupun keluhan tentang kinerja pelayanan publik pemerintah dapat diketahui. Dengan demikian, pemerintah dapat mengukur seberapa jauh kinerjanya ditanggapi oleh masyarakat dan dapat menciptakan pelayanan publik yang diterima masyarakat. Dengan demikian dapat tercipta kepuasan pelayanan karena masyarakat memperoleh pelayanan sesuai dengan yang dibutuhkan dan diharapkan.

Partisipasi publik melalui dialog publik jumat memiliki pengaruh dalam mewujudkan praktik transparansi dan akuntabilitas di kabupaten Bojonegoro. Berikut ini peran Dialog Publik Jumat dalam mewujudkan praktik transparansi dan akuntabilitas di kabupaten Bojonegoro:

1. Meningkatkan kepercayaan publik

Melalui partisipasi publik, pemerintah kabupaten Bojonegoro dapat menghasilkan pelayanan berkualitas tinggi yang diinginkan masyarakat dan ketika pejabat publik menunjukkan integritas, kejujuran dan kepemimpinan moral melalui partisipasi publik. Hal ini dibuktikan dengan adanya perubahan positif kabupaten Bojonegoro dari tahun 2007 sampai tahun 2015. Tercatat pada tahun 2008, 80\% jalan Bojonegoro dalam kondisi buruk, sementara utang Bojonegoro mencapai $42 \%$ dari total anggarannya (Amir, 2019) . Tidak heran apabila pada tahun 2008 kabupaten Bojonegoro menjadi kabupaten paling miskin di Jawa Timur.

Kerusakan jalan dan jembatan yang sebelumnya 80\% pada tahun 2015 kerusakannya menurun menjadi 19,8\%. Dalam kurun delapan tahun, kemiskinan di 
Bojonegoro turun hingga 50 persen. Menurut World Bank, Bojonegoro masuk 10 kabupaten di Jawa Timur dengan kemampuan tercepat dalam mengurangi kemiskinan. Dimana persentase penduduk miskin sampai dengan tahun 2008 mencapai lebih dari 28 $\%$, sedangkan pada tahun 2015 persentase penduduk miskin kurang dari $14 \%$ (Amir, 2019). Dengan demikian partisipasi publik dapat mempengaruhi kepercayaan publik ketika pejabat publik menunjukkan integritas, kejujuran dan kepemimpinan moral melalui partisipasi publik.

2. Membentuk legitimasi masyarakat

Upaya pemerintah kabupaten Bojonegoro melakukan partisipasi publik melalui dialog publik jumat pada masa kepemimpinan Suyoto untuk menciptakan pelayanan publik berdasarkan kebutuhan masyarakat melalui komunikasi yang dialegis. Pelayanan publik dapat dijadikan tolak ukur keseriusan pemerintah dalam menjalankan tanggung jawabnya, khususnya melayani masyarakat. Dengan demikian dapat tercipta kepuasan pelayanan karena masyarakat memperoleh pelayanan sesuai dengan yang dibutuhkan dan diharapkan. Hal ini ditegaskan juga oleh pendapat Suyoto saat wawancara bahwa, "Dari survey, orang yang tadinya puas sama pemerintahan itu cuma 35\% di 2008. Sekarang survey terakhir saya 73\%”. Prinsip kepuasan masyarakat dalam proses pelayanan publik yang dilakukan pemerintah sangat penting karena hanya dengan memenuhi kebutuhan masyarakat, keberadaan pemerintah itu diakui dan mendapatkan legitimasi masyarakat.

3. Memperbaiki pengambilan keputusan dengan melibatkan beragam kepentingan dan mencari solusi yang lebih ekonomi

Secara umum, ketika pemerintah mendorong konsultasi dan keterlibatan publik, mereka akan mendapatkan ide-ide baru serta masukan dari warga negara mengenai kebijakan dan layanan, sehingga meningkatkan kualitas pemerintahan dan kepatuhan warga negara terhadap pemerintah.

\section{Tantangan}

Meskipun Dialog Publik Jumat sudah terlaksana sampai dua periode masa kepemimpinan Suyoto, bukan berarti tidak ada tantangan yang dapat menjadi 
kendala. Menurut Suyoto (2018), ada beberapa tantangan yang dapat menjadi kendala dalam kelangsungan Dialog Publik Jumat tersebut, antara lain:

1. Beberapa pejabat publik belum siap menghadapi masyarakat pada Dialog Publik Jumat

Pada awal Dialog Publik Jumat, kepala-kepala Satuan Kerja (Satker) tidak suka dengan adanya dialog ini. Hal ini dikarenakan dengan adanya Dialog Publik Jumat, kepala Satker tersebut kehilangan privilege di depan masyarakat. Bahkan beberapa tokoh lokal juga merasa tidak nyaman dengan adanya dialog ini. Beberapa Kepala Desa sempat protes karena merasa harkatnya diinjak-injak oleh masyarakat. Upaya yang dilakukan dalam rangka mengatasi tantangan tersebut adalah dengan menonjolkan peran pemimpin sebagai coach. Dimana pemimpin menjembatani supaya tidak ada yang merasa disudutkan. Dengan demikian, peran pemimpin sangat kuat dalam mengatasi tantangan terkait hal tersebut.

2. Mental belajar beberapa pejabat publik masih rendah

Keberhasilan Dialog Publik Jumat tersebut sangat pengaruhi oleh adanya mental belajar pejabat publik yang tinggi. Namun pada awal dialog publik, kondisi yang terjadi justru pejabat publik tersebut kurang belajar dan memiliki mental tertutup. Hal ini dapat menjadi kendala, dimana beberapa pejabat publik yang masih memiliki mental belajar rendah tersebut dapat menghambat kinerja beberapa pejabat publik lainnya yang memiliki mental belajar yang tinggi. Selain itu juga menjadikan citra instansinya di muka publik kurang baik yang dapat mengurangi kepercayaan publik. Dalam rangka mengatasi tantangan tersebut, maka pejabat publik dituntut untuk menanggapi aspirasi masyarakat secara langsung sesuai dengan bidang masingmasing. Oleh karena itu, pejabat publik harus mampu memberikan tanggapan terbaik atas aspirasi masyarakat sesuai dengan aturan yang ada. Hal tersebut mendorong pejabat publik untuk terus belajar mempersiapkan tanggapan-tanggapan terbaiknya pada dialog publik jumat.

3. Keterlibatan masyarakat dalam Dialog Publik Jumat belum merata

Kegiatan Dialog Publik Jumat dapat diakses oleh semua masyarakat kabupaten Bojonegoro. Akan tetapi masih kendala terkait keterlibatan masyarakat yaitu tidak 
semua masyarakat di kabupaten Bojonegoro mengikuti dialog publik dan mendengarkan radio yang menyiarkan program dialog publik jumat. Upaya yang dilakukan pemerintah mengatasi tantangan tersebut adalah terus berupaya melakukan diseminasi agar informasi yang didapatkan di dialog publik penyebarannya lebih merata lagi. Saat ini pemerintah berupaya untuk melakukan diseminasi dengan cara mengadakan dialog publik secara bergilir di setiap kecamatan. Hal ini dilakukan agar dialog publik jumat tidak hanya banyak diikuti oleh masyarakat kota dan pinggiran kota, namun secara menyeluruh.

\section{KESIMPULAN DAN SARAN}

Pembelajaran dari inovasi partisipasi publik melalui dialog publik di kabupaten Bojonegoro adalah: (a) pentingnya komunikasi langsung antara pejabat publik dan masyarakat; (b) pentingnya peran pemimpin sebagai pelatih; dan (c) partisipasi publik memastikan bahwa pemerintah selalu terhubung dengan masyarakatnya. Adanya komunikasi secara dialogis antara pejabat publik dan masyarakat sangat penting dalam hal memperbaiki pengambilan keputusan dengan melibatkan beragam kepentingan. Adanya komunikasi secara dialogis, secara tidak langsung juga dapat menciptakan semangat belajar pada masyarakat dan pejabat publik itu sendiri. Keterlibatan masyarakat dalam tata kelola pemerintahan meningkatkan pemahaman masyarakat akan isu melalui keterlibatannya dalam aktivitas pemerintahan.

Peran pemimpin sebagai pelatih agar pimpinan dapat menjembatani masyarakat dan pejabat publik dalam meningkatkan transparansi dan akuntabilitas. Dengan bertindak sebagai pelatih, pimpinan tidak bertindak sebagai hakim, sehingga tidak ada yang merasa disudutkan karena pelatih tersebut berada ditengah-tengah masyarakat dan pejabat publik sebagai fasilitator. Kemudian peran pelatih menarik benang merah pelajaran-pelajaran ataupun nilai-nilai garis besar dari sistem mekanisme yang telah sepakati bersama antara masyarakat dan pejabat publik.

Partisipasi publik memastikan bahwa pemerintah selalu terhubung dengan masyarakatnya. Maksud terhubung disini adalah peraturan yang dibuat pemerintah tersebut harus bisa dipahami masyarakat, biar maksud dari peraturan tersebut tidak 
disalahartikan oleh masyarakat. Selain itu maksud setiap program pemerintah sesuai dengan kebutuhan masyarakat. Dengan adanya partisipasi publik melalui dialog publik tersebut dapat memastikan bahwa peraturan yang dipikirkan dan yang dilakukan pemerintah sesuai dengan kebutuhan masyarakat dan dapat dipahami masyarakat. Cara seperti ini merupakan cara yang efisien dan murah untuk meningkatkan kepercayaan publik dan mendapatkan legitimasi masyarakat.

\section{REFERENSI}

Amir, M. 2019. Gaya Kepemimpinan Transformatif Pemerintah Kabupaten Bojonegoro Dalam Penanggulangan Bencana BanjiR (Studi Di Pemerintah Kabupaten Bojonegoro). University of Muhammadiyah Malang.

Duadji, N. 2013. Partisipasi publik dalam pengambilan keputusan anggaran pendapatan dan belanja daerah (APBD) Provinsi Lampung. Jurnal Bina Praja: Journal of Home Affairs Governance, 5(3), 197-203.

Habibah, B. A. 2017. Efektivitas Dialog Jumat sebagai Model Pembuatan Kebijakan Publik Deliberatif di Kabupaten Bojonegoro. Universitas Airlangga.

Kim, S., \& Lee, J. 2017. Citizen Participation and Transparency in Local Government: Do Participation Channels and Policy Making Phases Matter? Proceedings of the 50th Hawaii International Conference on System Sciences.

Lauranti, M., Djamhari, E. A., \& Mawesti, D. 2017. Open Government: Mengkaji Penggunaan e-government Pemerintah Daerah di Indonesia.

Musthofa, Y. 2016. Bojonegoro Inspirasi untuk Negeri. Jakarta: INFID (International NGO Forum on Indonesia Development).

Nawawi, J. 2012. Membangun kepercayaan dalam mewujudkan good governance. Jurnal Ilmiah Ilmu Pemerintahan, 1(3), 19-29.

Safarov, I., Meijer, A., \& Grimmelikhuijsen, S. 2017. Utilization of open government data: A systematic literature review of types, conditions, effects and users. Information Polity, 22(1), 1-24.

Sharma, B. 2008. Voice, accountability and civic engagement: A conceptual overview. Paper Commissioned by Oslo Governance Centre, Bureau for Development Policy, United Nations Development Programme. Overseas Development Institute, London.

Undang-Undang Nomor 14 Tahun 2008 tentang Keterbukaan Informasi Publik 